\title{
Maxillary Reconstruction with Free Fibular Flap using 3D RP Model
}

\author{
Kang-Min Ahn, D.D.S., M.S.D., Ph.D. ${ }^{1}$, Jong-Jin Kim, D.D.S. ${ }^{2}$ \\ ${ }^{1}$ Department of oral and maxillofacial surgery, College of medicine, University of Ulsan, Asan medical center \\ ${ }^{2}$ Department of prosthodontics, Asan medical center
}

\begin{abstract}
Reconstruction of the maxilla is quite a difficult challenge for reconstructive surgeons. The maxilla is the most important part of the midface, which contributes to facial esthetics, mastication, swallowing, speech, supporting orbital contents and sinus function. Free fibular flap is most versatile to reconstruct jaw bone because of its adequate length, containing both soft and bony tissues and acceptance of dental implants. In this case report, a reconstruction of the maxilla using free fibular flap and dental implants is described in which rapid prototype was used before surgery to simulate the final prosthetic results.
\end{abstract}

Key Words Maxilla $\cdot$ Reconstruction $\cdot$ Free fibular flap $\cdot 3 \mathrm{D} \cdot$ Rapid prototype.

Received: July 6, 2014 / Revised: July 11, 2014 / Accepted: July 15, 2014

Address for correspondence: Kang-Min Ahn, D.D.S., M.S.D., Ph.D

Department of oral and maxillofacial surgery, College of Medicine, University of Ulsan, Asan Medical Center, 88 Olympic-ro, 43-gil, Songpa-gu, Seoul,

Korea

Tel: 02-3010-5901, Fax: 02-3010-6967, E-mail: ahnkangmin@hanmail.net

서 론

상악골은 중안모에서 중요한 위치를 차지하며 코와 눈, 광대 를 바치고 있기 때문에 상악골이 절제 되면 심미적으로 큰 영향 을 미친다. ${ }^{1}$ 상악골은 상악동, 안와, 비강의 일부를 이루고 있으 며 골조직, 치아를 포함하고 상악동 내면은 점막으로 이루어져 있 으며 비강과 구강 및 상악동을 분리하고 있다. 상악골에 발생한 암종을 제거한 뒤에 국소피판, 유경피판 이나 유리피판을 이용 하여 재건을 하거나 틀니를 사용하여 구강-상악동-비강 부위 를 막을 수 있지만 사용하는 틀니는 유지력을 얻기 힘들어서 사용 에 불편을 호소한다. ${ }^{2}$ 치과 임플란트의 개발은 치아 결손의 보철 치료에 획기적인 혁신을 가져 왔으며 특히 악골결손부위나 무치 악 환자의 틀니 사용과 같이 시행하면 환자의 만족감을 최대로 높일 수 있다. ${ }^{1}$ 본 보고에서는 상악골에 발생한 선양낭포암 (adenoid cystic carcinoma)를 제거하고 난 뒤 결손된 상악골에 3 차원 Rapid prototype (RP) 모델을 이용하여 유리비골피판과 치과 임플란트를 이용하여 재건한 증례를 보고하고자 하였다.

\section{증례 보고}

1. 1차 비골피판 재건 수술

34 세 여자 환자가 서울아산병원 구강악안면외과로 의뢰되었 다. 환자는 1998년 좌측 상악에 발생한 선양낭포암으로 좌측 상악골 전 절제술과 우측 상악골 부분 절제술을 받았으며 광배 근 피판을 이용하여 재건을 받았다. 1999년 좌측 경부에 임파 절 전이로 인하여 좌측 경부 임파선 절제술을 받았으며 이후 방 사선 치료를 추가적으로 받았다. 환자는 이후 암종의 재발없이 지내 왔으나 안면의 지속적인 변형과 비변형, 치아의 우식증으 로 인하여 안면함몰과 치과보철치료를 위하여 2006년 12 월 치 과를 방문 하였다. 치과파노라마 영상사진 촬영 결과 좌측 상악 골 및 관골이 절제되어 있었으며 우측 상악골이 견치부위까지 절제 되어 있었다. 하악에는 잔존 치근이 하악전치부에 4 개 남 아 있었으며 좌측 하악 제 3 대구치가 매복 되어 있었다. 하악골 에는 방사선 치료 이후에 발생한 방사선골괴사증이 의심되었으 며 골조직의 파괴가 관찰 되었다 (Fig. 1).

비변형과 안면 함몰의 우선 수술을 위하여 본원 이비인후과 
에서 2006년 12 월 11 일 비성형 수술과 좌측 안면과 협부의 증 강술을 시행하였다. 좌측 상악골의 결손이 있어서 타이타늄 금 속판을 이용하여 상순의 지지를 하였다. 2007년 1월 좌측 협부 증강술 시행한 부위 감염 소견 보이고 보철 치료를 원하여 구강 악안면외과로 의뢰되어 상악골을 재건과 치과 임플란트 치료를 하기로 하였다. 수술전 준비로 두경부의 3 차원 전산화촬영 (CT) 을 시행하였으며 $1: 1$ 비율의 3차원 모델을 제작 하였다(Fig. 2).

상악의 재건을 위하여 타이타늄 금속판을 제거하고 우측 상 악에서 좌측 관골까지 재건 될 양을 3차원 모델과 왁스를 이용 하여 재현하였다 (Fig. 3). 우측 상악골에서 좌측 관골까지 $7 \mathrm{~cm}$ 의 골결손을 보였으며 유리비골피판이 가장 유용한 피판으로 판

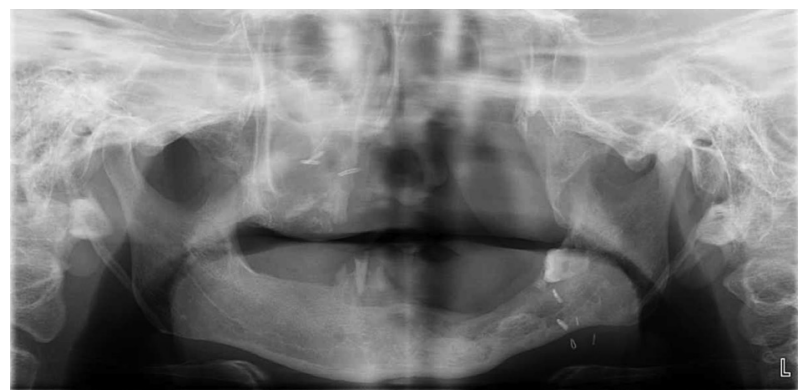

Fig. 1. Initial panoramic radiograph showing left maxilla defect and loss of teeth.

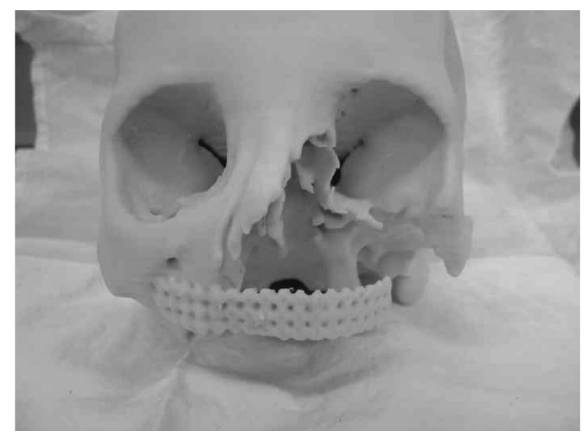

Fig. 2. (dimensional) Rapid prototype model after rhinoplasty and titanium mesh augmentation.

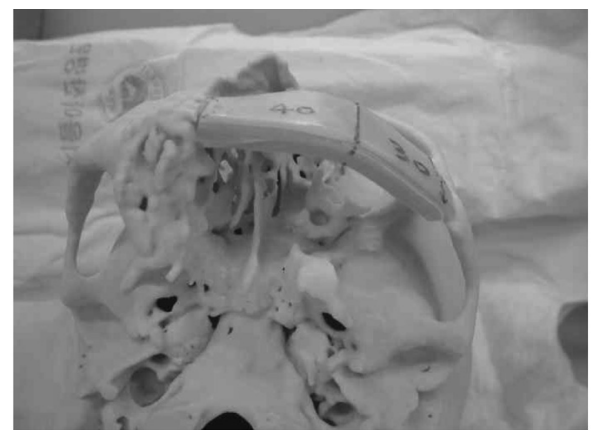

Fig. 3. Simulation of the maxillary reconstruction with 3-D rapid prototype and baseplate wax.
단되었다. 구강내 점막의 결손부위를 추가적으로 재건하기 위하 여 유리비골피판은 피부를 포함하는 골피부피판을 채취하기로 계획하였다. 비골피판의 두께가 $1.5 \mathrm{~cm}$ 이상되어 임플란트를 식 립 하기에는 이상적인 피판이며 한번의 골절단으로 상악과 관골 의 원래 외형을 재현할 수 있었다. 왁스로 제작된 골결손부는 다시 알지네이트에 매몰하여 레진블록으로 제작 하여 수술중에 사용할 수 있도록 소독 하였다.

2007년 2월 8일 전신마취하에 수술을 시행하였으며 베버-퍼 거슨 (Weber-Ferguson)절개를 이용하여 좌측 상악 및 관골 부위를 노출 시켰으며 환자의 좌측 비골피판을 채취하였다. 측 후방 접근법을 이용하여 피부피판을 포함하는 피부-골 비골피 판 채취를 하였다. 비골동맥과 같이 주행하는 2 개의 정맥을 채 취하였으며 상악의 형태에 맞게 골절단을 시행하여 소형금속판 (Leibinger, Stryker, San Diego, USA)을 이용하여 고정 하 였다 (Fig. 4).

채취한 비골피판은 우측 상악과 좌측 관골에 위에서 사용된 소형금속판을 이용하여 고정 하였으며 비골동맥은 좌측 안면 동맥에 연결 하였으며 2개의 같이 주행하는 정맥 (venae comitantes)은 안면 정맥에 한 정맥은 순방향으로 한 정맥은 역방 향으로 연결 하였다 (Fig. 5).

수술 후 1 주일 뒤 골스캔 검사를 시행하여 피판의 생존 여부 를 판단 하였으며 구강내 피판에 도플러를 이용하여 피판의 생

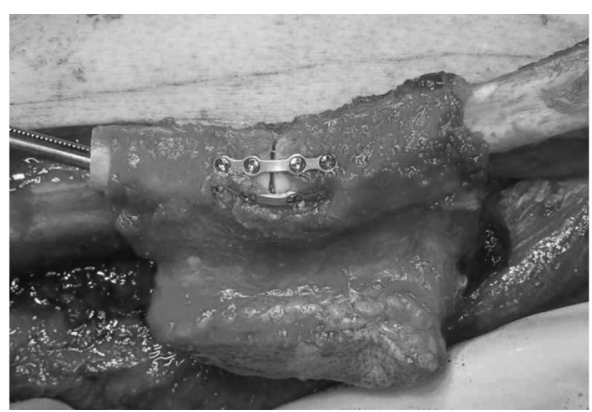

Fig. 4. Osteotomizedosteo-cutaneous fibular free flap fixed with miniplate.

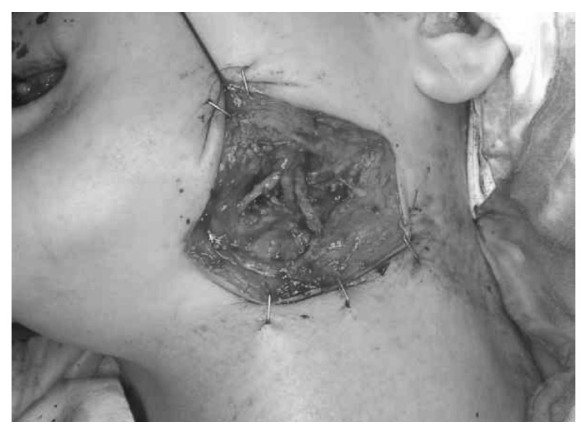

Fig. 5. Microvessels anastomosis of the peroneal and facial artery. 
존을 같이 조사 하였다. 골스캔 검사 결과 피판으로 혈류 공급 이 원활하게 되고 있었으며 hot spot를 보여 피판이 잘 생존하 였음을 관찰 하였다 (Fig. 6).

\section{2. 치과 임플란트 식립수술}

비골피판으로 재건 하고 난 뒤 4 개월 후 악골의 재건 상태를 3 차원 $\mathrm{CT}$ 를 촬영 하여 관찰 하였으며 임플란트의 식립 위치를 결정 하였다. 상 하악골의 전후 위치 관계가 골격성 Class III로 관찰 되어 상악골에 식립할 임플란트 위치는 순측으로 위치하 여 식립 하여야 하였으며 하악골에는 방사선 치료를 받아서 좌 측 하악골에는 골결손부가 커서 임플란트를 식립할 부위가 없었 으며 우측에 최대한 많은 임플란트를 식립하여 추후 실패하는 임플란트가 발생하여도 여유가 있도록 하였다 (Fig. 7).

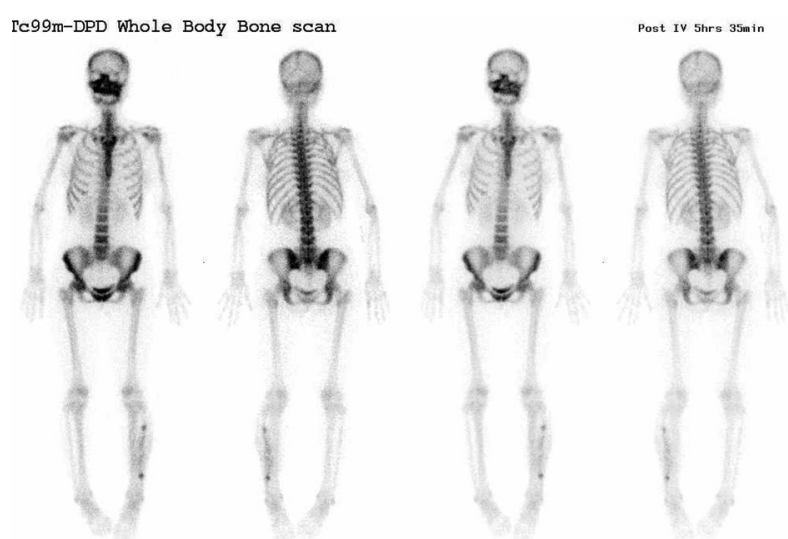

Fig. 6. Bone scan image after fibular free flap reconstruction. Hot spot is observed in the maxillary area.

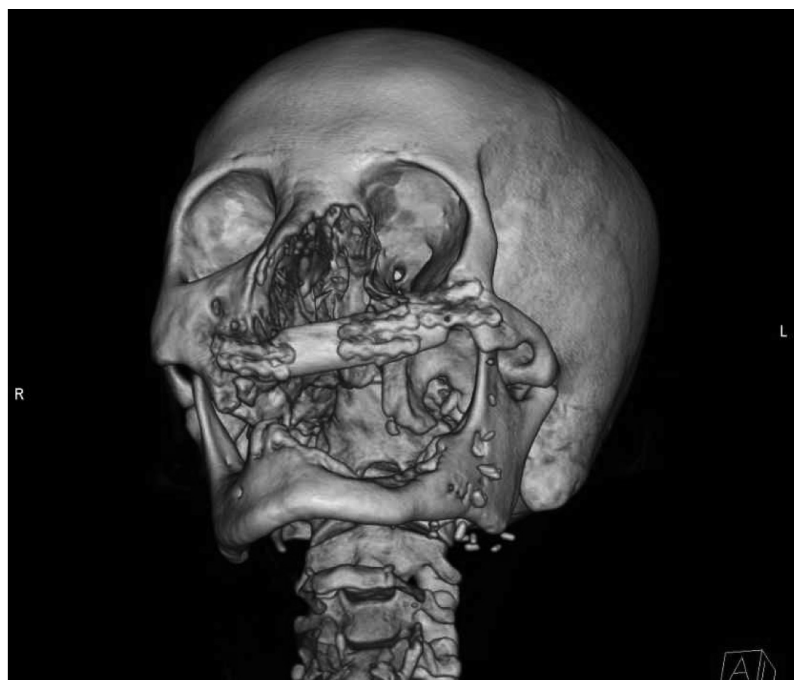

Fig. 7. 3D CT reconstruction before dental implant operation. Site of implants placement has been decided using 3D simulation and surgical stent.
2007년 6월 27일 전신마취하여 비골로 재건된 상악골과 우 측 상악골에 임플란트 시술을 시행하였다. 비골피판의 고정에 사용되었던 소형금속판은 제거하고 난 뒤 임플란트를 위한 스텐 트를 장착하고 임플란트의 식립위치를 표시하였다 (Fig. 8).

상악 우측 구치부은 상악동의 함기화로 인하여 상악동 거상 술 및 골이식이 요하였으며 상악에는 상악동 거상술 과 골이식 (Bio-Oss, Geistlich, Switzerland) 후 6개의 임플란트 (Dentis implant, Dentis, Daegu, Korea)와 하악에도 같은 제품의 임플란트를 8개 식립하였다 (Fig. 9).

\section{3. 임플란트 2차 수술 및 보철치료}

임플란트 식립 후 4 개월 반 뒤 식립된 임플란트의 노출을 위 한 2 차 수술을 시행하였다. 수술은 국소 마취로 시행하였으며 전층 피판 절개 후 피판을 거상하여 치근단위치 피판을 형성하 여 임플란트를 노출하고 지대주 (healing abutment)를 연결하 였다. 이후 환자는 치과 보철과에 의뢰되어 인상채득 하였으며 보철물 연결하였다 (Fig. 10).

환자는 보철치료 후 정상식이가 가능하게 되었으며 비골재건 수술 후 6 년간 추적관찰 기간 동안술후 저작 기능 및 심미에 만 족 하였다.

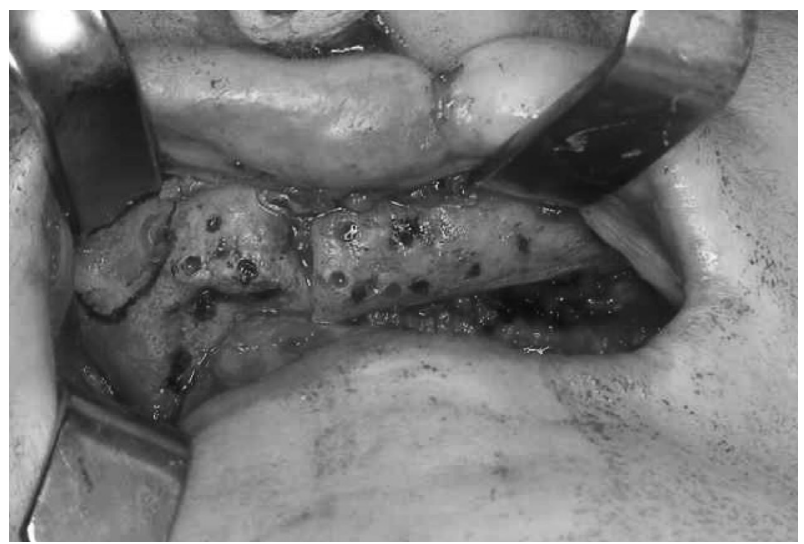

Fig. 8. Exposed maxilla and fibular bone for implant surgery.

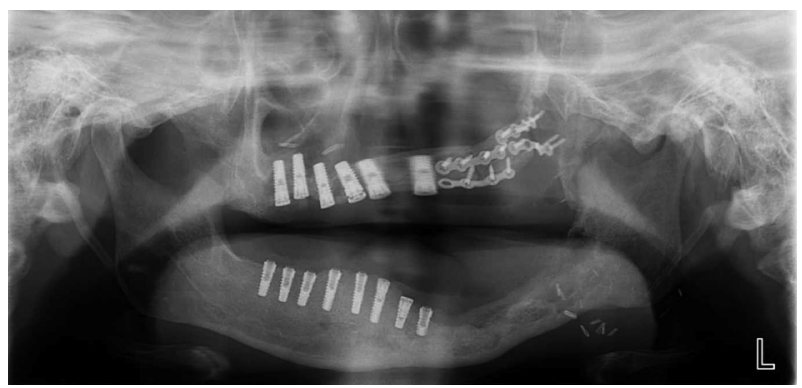

Fig. 9. Radiograph after implants placement. A total of $14 \mathrm{im}-$ plants have been placed. 


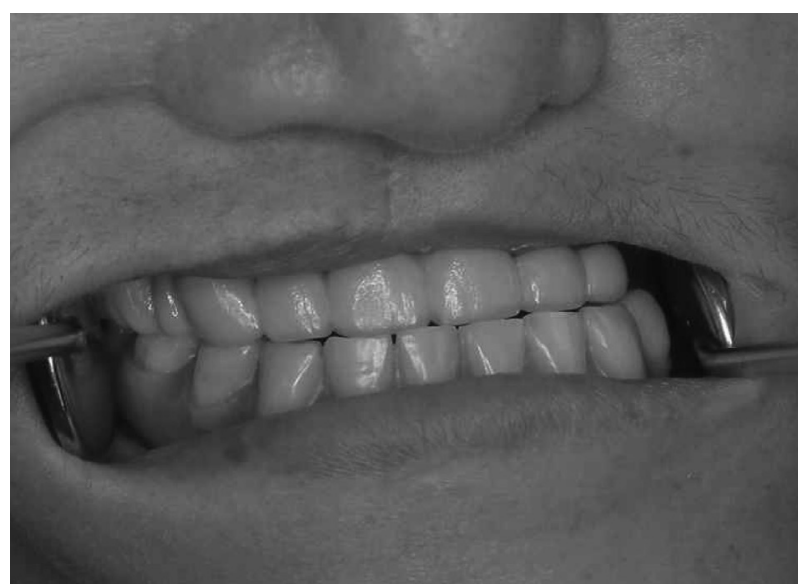

Fig. 10. Definitive prosthetic restoration.

\section{고 찰}

상악골의 재건은 3 차원적인 형태와 주위 주요 구조물과의 관 계, 심미적인 중요성으로 인하여 환자의 삶에 큰 영향을 미친다. 상악골에 발생한 구강암의 절제 후 상악골의 재건은 필수적이 며 구강악안면외과의사는 암의 제거와 재건을 환자의 결손부위 에 맞게 국소피판, 유경피판, 유리피판재건과 틀니를 이용한 재 건의 중 현명하게 선택하여야 한다. ${ }^{3}$ 본 증례에서는 상악골의 암 을 수술 하고 나서 9 년이 경과하여 안모비대칭이 심한 환자의 수술이어서 수술의 난이도가 암의 제거 후 즉시 재건보다는 높 았다. 암의 제거와 동시에 수술한 경우에는 제거된 상악골의 형 태를 수술중에 파악하여 재현하기가 쉽지만 2차적인 재건인 경 우 해부학적 위치가 변형되어 재건에 어려움이 많다. 그리고 골 조직으로 재건 해야 하는 공간에 과거에 사용된 피부-근육 피 판으로 채워져 있어서 수술시 조직을 일부 제거하고 재건 해야 하는 어려움도 있었다. 본 증례는 1차 수술한지 9년 이상 경과 하여 연조직의 긴장도가 높아서 수술 후 재건한 부분의 지속적 인 부피감소도 예측을 해야 했다. 수술 후 방사선 치료를 받았 기 때문에 방사선 골괴사증이 발생하지 않도록 최소한의 절개를 통하여 수술 하는 것 역시 중요했으며 남아있는 하악의 잔존치 를 발치 할 때도 주의를 요하였다. 수술 후 구강내 점막의 치유 는 합병증 없이 치유 되었으며 발치 한 부위에도 방사선 골괴사 증이 발생하지 않았다.

유리비골피판은 상하악골의 재건에 가장 유용한 피판이다. ${ }^{4}$ 1989년 Hidalgo에 의해 하악골의 재건에 사용된 것이 발표 된 이후에 하악골 및 상악골의 재건에 가장 흔히 사용된다. ${ }^{5}$ 유리 비골피판은 충분한 길이의 골조직을 가지고 있고 피부조직을 동 시에 이식 할 수 있어서 복합조직을 제거 해야하는 구강암 수술 후 재건에 특히 유용하다. 그리고 비골피판은 임플란트를 식립
할 수 있기 때문에 재건시 반드시 추후 임플란트 식립이 가능한 위치에 골 조직을 재건해야 하며 임플란트와 최종 보철물을 들 어갈 위치를 미리 재현해야 한다. 이를 위해 최근에는 3 차원 입 체 영상을 미리 제작 하여 상악골 재건 수술 전에 미리 재현하 여 정확한 위치 및 임플란트 식립이 가능하다고 하였다. ${ }^{6-8}$ 본 증례 에서도 수술전에 상하악 및 두개골과 하악골의 $3 \mathrm{D} \mathrm{RP}$ 모 델을 제작 하여 재건 후에 하악과 상악의 위치를 먼저 재현 하 였으며 이를 토대로 임플란트의 위치를 미리 파악 하였다. 오랜 기간 상악의 결손과 하악치아의 발치로 인하여 상악골은 후방 으로 퇴축되고 하악골은 전방으로 퇴축되어 골격성 Class III 형태를 보여 임플란트 식립 시에도 상악 전치부의 임플란트가 순측으로 식립되어야 하였다. 이를 위해서는 상악의 재건시 부 족한 연조직의 재건을 위하여 비골피판 채취시 피부피판을 포함 하여 재건하여 추후 임플란트 보철시 필요한 구강전정을 확보하 였다.

수술전에 제작한 3 차원 모델은 수술전에 미리 수술 중이나 수술 후의 결과를 예측하는데 유용하게 사용된다. 본 증례에서 도 미리 제작한 $\mathrm{SD} \mathrm{RP}$ 모델을 이용하여 골결손 정도와 비골피 판의 골절단 부위 및 각도를 미리 계산하여 스텐트를 제작 하고 그것을 이용하여 수술 중에 비골피판을 작도 하였다. 수술중에 스텐트를 이용하여 골절단을 하게 되면 비골피판의 혈관경을 절 단 하지 않고 디자인을 하여 피판의 허혈시간을 감소 시킬수 있 으며 피판의 생존도 높일수 있다. 본 증례에서 비골피판의 혈관 경을 절단하고 피판을 잔존 상악과 관골에 고정 시키고 나서 안 면동맥에 연결 하기 까지의 허혈시간이 1 시간 정도로 허혈시간 을 최소화 할 수 있었으며 수술 시간도 줄일 수 있었다.

이식한 비골피판에 임플란트를 식립하는 연구는 다양하게 많 이 발표 되며 환자의 만족도 상당히 높다. ${ }^{4-9-18}$ 비골피판을 이식 한 뒤에 임플란트를 식립하는 기간은 다양하며 최소 4 개월의 치 유 기간을 기다린 뒤 식립하는 것이 추천된다. 본 증례에서도 비 골피판을 이식 한 뒤 4 개월 반을 기다린 뒤 임플란트를 식립 하 였으며 임플란트를 식립하기 위해 피판을 거상 하였을 때 잔존 상악골과 완전히 골결합이 된 비골피판을 확인 할 수 있었다.

임플란트는 지속적으로 관리를 요한다. 본 증례에서 환자는 임플란트 시술 및 보철 치료 후 만족할 만한 기능을 보였으며 수술전에 유동식만 하다가 보철 치료 후 정상 식이를 하게 되었 다. 환자는 6 개월 간격으로 내원을 권유 받았으나 시술 후 3 년 째 지방 거주 관계로 내원을 못하여 정기적인 치주 치료를 받지 못하여 상악 전치부에 임플란트 주의염이 발생하여 이후 치료를 받고 있는 상태이며 현재는 잘 유지 되고 있다. 환자의 장기적인 임플란트 유지를 위하여 주기적인 치주 치료 및 관리는 필수 적 이다. 


\section{결 론}

상악의 결손에 3 차원 모델 (3D RP model)을 이용한 재현수 술 (simulation surgery)은 수술중의 오차를 줄이고 수술시간 을 감소시키는데 유용하다. 유리비골피판과 치과임플란트를 이 용한 상악의 재건은 환자의 심미를 높이고 삶의 질을 높이고 구 강기능의 개선으로 정상적인 식이를 가능하게 한다.

\section{참고 문 헌}

1. Gbara A, Darwich K, Li L, Schmelzle R, Blake F. Long-term results of jaw reconstruction with microsurgical fibula grafts and dental implants. J Oral Maxillofac Surg 2007;65:1005-1009

2. Yetzer J, Fernandes R. Reconstruction of orbitomaxillary defects. J Oral Maxillofac Surg 2013;71:398-409

3. Fierz J, Hallermann W, Mericske-Stern R. Patients with oral tumors. Part 1: Prosthetic rehabilitation following tumor resection. Schweiz Monatsschr Zahnmed 2013;123:91-105

4. Lee JH, Kim MJ, Choi WS, Yoon PY, Ahn KM, Myung H et al. Concomitant reconstruction of mandibular basal and alveolar bone with a free fibular flap. Int J Oral Maxillofac Surg 2004;33:150-156

5. Hidalgo DA. Fibula free flap: A new method of mandible reconstruction. Plast Reconstr Surg 1989;84:71-79

6. Rude K, Thygesen TH, Sorensen JA. Reconstruction of the maxilla using a fibula graft and virtual planning techniques. BMJ Case Rep 2014;2014

7. Nkenke E, Eitner S. Complex hemimaxillary rehabilitation with a prefabricated fibula flap and cast-based vacuum-formed surgical template. J Prosthet Dent 2014;111:521-524

8. Okay DJ, Buchbinder D, Urken M, Jacobson A, Lazarus C, Persky M. Computer-assisted implant rehabilitation of maxillomandibular defects reconstructed with vascularized bone free flaps. JAMA Otolaryngol Head Neck Surg 2013;139:371-381
9. Dawood A, Tanner S, Hutchison I. Computer guided surgery for implant placement and dental rehabilitation in a patient undergoing sub-total mandibulectomy and microvascular free flap reconstruction. J Oral Implantol 2013;39:497-502

10. Hakim SG, Kimmerle H, Trenkle T, Sieg P, Jacobsen HC. Masticatory rehabilitation following upper and lower jaw reconstruction using vascularised free fibula flap and enossal implants-19 years of experience with a comprehensive concept. Clin Oral Investig 2014

11. He Y, Zhang ZY, Zhu HG, Wu YQ, Fu HH. Double-barrel fibula vascularized free flap with dental rehabilitation for mandibular reconstruction. J Oral Maxillofac Surg 2011;69:2663-2669

12. Jambhekar SS, Kheur MG, Dandagi S, Matani JD, Sethi S, Kheur SM. Total mandibular reconstruction and rehabilitation: A case report. J Oral Implantol 2014

13. Mertens C, Decker C, Engel M, Sander A, Hoffmann J, Freier K. Early bone resorption of free microvascular reanastomized bone grafts for mandibular reconstruction - a comparison of iliac crest and fibula grafts. J Craniomaxillofac Surg 2014;42:e217-223

14. Ooi A, Feng J, Tan HK, Ong YS. Primary treatment of mandibular ameloblastoma with segmental resection and free fibula reconstruction: Achieving satisfactory outcomes with low implant-prosthetic rehabilitation uptake. J Plast Reconstr Aesthet Surg 2014;67:498-505

15. Peng X, Mao C, Yu GY, Guo CB, Huang MX, Zhang Y. Maxillary reconstruction with the free fibula flap. Plast Reconstr Surg 2005;115:1562-1569

16. Raoul G, Ruhin B, Briki S, Lauwers L, Haurou Patou G, Capet JP et al. Microsurgical reconstruction of the jaw with fibular grafts and implants. J Craniofac Surg 2009;20:2105-2117

17. Shen YF, Rodriguez ED, Wei FC, Tsai CY, Chang YM. Aesthetic and functional mandibular reconstruction with immediate dental implants in a free fibular flap and a low-profile reconstruction plate: Five-year follow-up. Ann Plast Surg 2013

18. Smolka K, Kraehenbuehl M, Eggensperger N, Hallermann W, Thoren $\mathrm{H}$, Iizuka $\mathrm{T}$ et al. Fibula free flap reconstruction of the mandible in cancer patients: Evaluation of a combined surgical and prosthodontic treatment concept. Oral Oncol 2008;44:571-581 